\author{
Józef Rabiega \\ dr inż. \\ Politechnika Wrocławska \\ Wydział Budownictwa Lądowego i Wodnego \\ Katedra Mostów i Kolei \\ jozef.rabiega@pwr.edu.pl
}

DOI: $10.35117 /$ A ENG $17 \quad 10 \quad 04$

\title{
Investigation of the truss spans of railway bridge under operating load
}

\begin{abstract}
The paper presents a description of the structure and its damage and a report on study under the operating load of three truss spans of $42.0 \mathrm{~m}$ length each. The spans are located in track no. 2 of two tracks railway Chorzów Batory - Tczew. They crosses the Warta River and its flood terrain in Działoszyn. Following spans are located along track no. 2: one steel beam span of $12.0 \mathrm{~m}$, three truss spans of $42.0 \mathrm{~m}$, one truss span of $32.0 \mathrm{~m}$. The spans were built in 1941/42. They are rivet structures with parabolic shape and girders located under railway. A design of bridge repair and strengthening was prepared. Due to lack of funds the repair works were delayed, but all spans were in bad technical condition. Three the longest ones, which had been examined, had low lateral flexibility. Lateral vibration were noticed, which were consider to be dangerous with a speed limit on the bridge $\mathrm{v} \leq 100 \mathrm{~km} / \mathrm{h}$ and load class of $\mathrm{k}=+2, \alpha \mathrm{k}=1,21$ (according to Polish code). The tests result forced the owner to start repair work immediately (mainly to install lateral stiffeners in all spans to eliminate vibrations). It was done by KPRM Kielce company which was already performing repair works at track no. 1.
\end{abstract}

Keywords: Truss; Bridge; Railway

\section{Introduction}

The bridge crossing is located in km 111.320 of the double-track mainline No. 131 Chorzów Batory - Tczew on the Annolesie - Działoszyn route and crosses the Warta river and its floodplains. The electrified line No. 131 is called "Węglówka", used for the export of coal from Silesia to the Ports of the Baltic Sea. In each of the tracks, the supporting structure of the bridge is made up of five steel spans with mountain running and an open pavement on the bridges. Spans under track No. 1 were made in 1932 together with supports for both tracks, while spans under track No. 2 were made in 1941/42 by Beuchelt u. Co from Zielona Góra. Currently, these spans count 66 years of use. All eight lattice spans of the bridge and two girders in both tracks were made completely riveted. Both old span girders due to the presence of extensive corrosion losses and limited load capacity were replaced with new fully welded spans, along with the adjustment of underfoot strikes and replacement of bearings. All four lattice bays in track No. 1 were renovated and renovated as part of the main repair in 1998. Before transferring them to re-use, they were subjected to trial static and dynamic loads $[1,6]$, whose results were positive and it was possible to restore the use of the object without 
any traffic restrictions at $\mathrm{v} \leq 100 \mathrm{~km} / \mathrm{h}$ and class load permissible $\mathrm{k}=+2$ according to $\mathrm{PN}-85$ / S-10030 [4]. The direct reason for performing dynamic tests under the operational load of the three longest lattice spans in track No. 2 were suspicions about the correctness of their construction work, augmented by excessive deflections, and in particular horizontal vibrations, even at a slight load. Therefore, it was concluded that the implementation of dynamic identification of the structure of these bridge spans by setting the value of the dynamic coefficient on the basis of tests under operating load, without additional vibration of the structure, will allow explaining the behavior of the spans. The results of these tests were to decide on the immediate renovation and strengthening of these spans according to the already developed project or were to be used to introduce traffic restrictions for their operational capacity in the event of prolongation of the date of commencing such renovation.

\section{Description of truss bridge span structures}

Laxity supported spans in track no. 2 have theoretical spans (counting from the Chorzów side): $12.0 \mathrm{~m}, 3 \times 42.0 \mathrm{~m}, 32.0 \mathrm{~m}$ and are located on the side of the lower water. The general situational sketch of the object is shown in Fig. 1. For the line on which the spans are built in, it is valid:

- load class $\mathrm{k}=+2$, or $\alpha_{\mathrm{k}}=1,21$,

- maximum operating speed $\mathrm{v}=100 \mathrm{~km} / \mathrm{h}$.

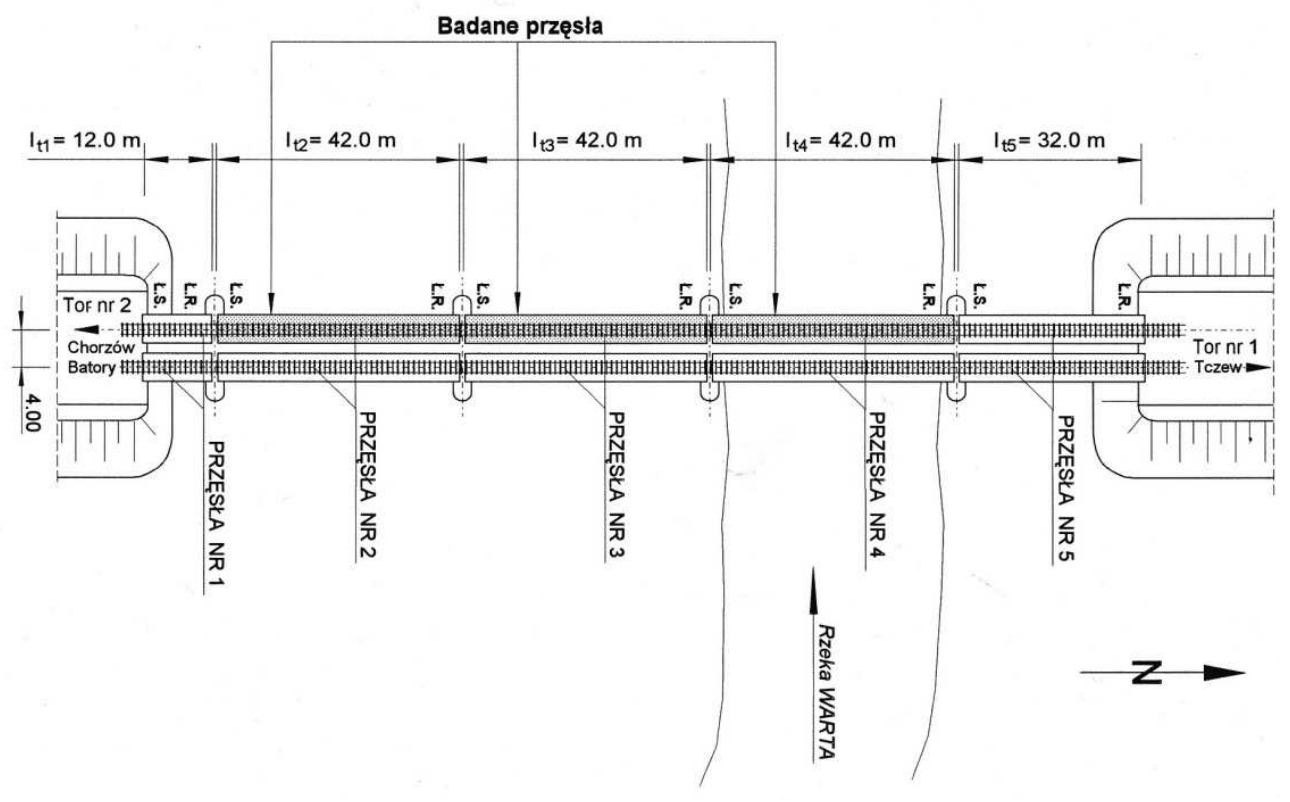

1. A situational sketch of the object's location in the field

Due to the poor technical condition of the span, the operational speed of the rolling stock on the bridge, until the repairs were carried out, was limited to $30 \mathrm{~km} / \mathrm{h}$. The railway track on the bridge is arranged in a straight line and horizontally. The main girders with the theoretical span of $42.0 \mathrm{~m}$ were made as trusses with mountain running with a lower curved belt according to the 2 nd degree parabola. The theoretical height of the truss over the supports is $2.28 \mathrm{~m}$ and in the middle of the span $6.60 \mathrm{~m}$. The axial spacing of the main girders is $2.40 \mathrm{~m}$. The cross members are riveted girders with a height of $0.60 \mathrm{~m}$, their webs are sharp. $600 \times 10$ $\mathrm{mm}$, and the lower and upper belt are 2 angle brackets 100x100x10 mm. The gusset plates at the joins of crossbars and main girders have a thickness of $10 \mathrm{~mm}$. Stringers from I-Beams 
300 with an axial spacing of $1.50 \mathrm{~m}$ are made as continuous beams resting on the upper belts of the cross-members. The bridge stays directly on the upper shelves of the stringers, without the mediation of the centering stools. In the level of the upper and lower flanges, the main lattice girders are braced with each other as a cross-section made as double cross-bracing lattice type X. The main girders were horizontally arranged in the vertical plane only above the supports. There are no such concentrations in the remaining fields between crossbars. A suitable technical project for such renovation and transverse stiffening of all four lattice spans of the bridge in track No. 2 was developed by BPKol in Katowice. The total mass of one span is about 10 tons. Supreme and intermediate bridge supports are massive, with stone cladding on cement mortar.

\section{Decision on the technical condition of the facility in track No. 2}

During the previous periodic inspections of this object, numerous damage was found to qualify spans and supports for the main repair in both tracks on the bridge. According to Instruction Id-2 [2] and Id-16 [3], a detailed inspection of the bridge in track No. 2 was also carried out (Fig. 2). As a result of the inspection of the spans, bearings and bridge supports, also using the diagnostic draisine of the Zakład Mostowy Kędzierzyn-Koźle, numerous damages were found, mainly within steel spans. Additionally, during the use of the spans in track no. 2, it was revealed that lattice bays no. 2, 3 and 4 suffer noticeable horizontal transversal displacements (vibrations). This phenomenon intensified during the passage of heavy freight trains. Initially, it was thought that this was due to inaccuracies on the support of the spans, mainly after widening the space to $4.0 \mathrm{~m}$. However, after adjusting bearings and repairing underarms, the phenomenon did not diminish, and as a result of subsequent inspections of the spans, cracks in gusset plates were found at the connections of the upper girders lattice with cross-bars and upper wind braces and extensive pitting and surface corrosion of these elements. A certain difficulty in accurately assessing the effects of damage and developing project documentation was the lack of archival drawings of all spans, which required supplementary inventory measurements.

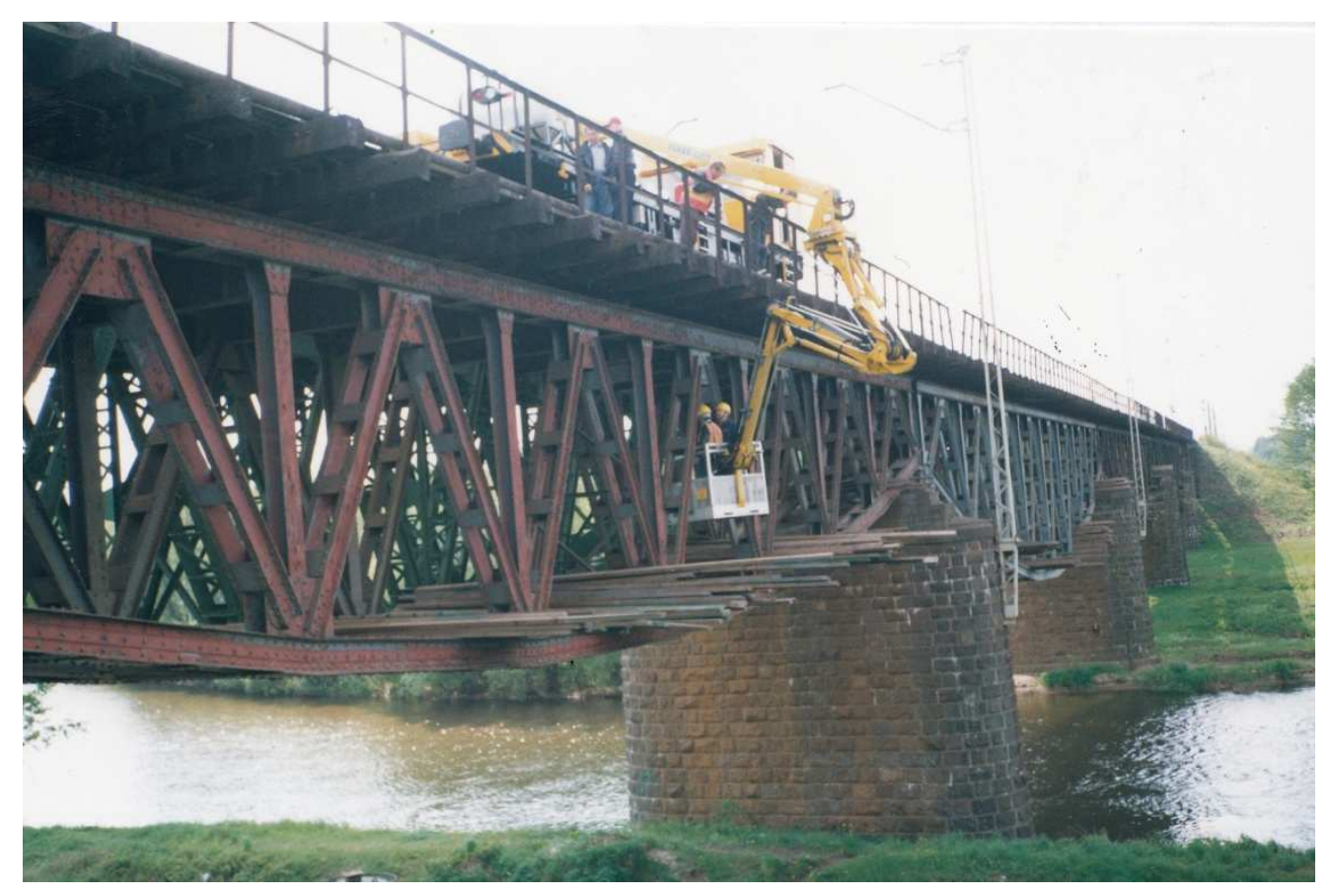

2. Detailed review of truss girders of the bridge spans 


\section{The course of research, analysis and interpretation of their results}

The following range of dynamic (operational) measurements was adopted during the planned railway vehicle railroad journeys without interrupting the normal rolling stock traffic on the site, at selected points of the three longest bridge mesh spans:

- measurement of unit deformations (indirectly stresses),

- measurement of vertical displacements (deflections),

- measurement of horizontal displacements,

- measurement of vertical and horizontal vibrations.

Normal values of dynamic coefficients in [4] are:

$\varphi=\frac{1,44}{\sqrt{2,625+3,0}-0,2}+0,82=1,483$ for stringers and $\varphi=\frac{1,44}{\sqrt{42}-0,2}+0,82=1,049$ the main truss girders.

The measuring points in bays 2 and 4 were:

- the upper longitudinal stripe in the middle of its span between the cross members (measurement of unit deformation, T1),

- the upper stripe truss girder mid-span length (measuring unit T2 strain, deflection I1, I2 and horizontal displacement of the vertical vibration frequency of the horizontal B1 and B2),

- the lower stripe in the middle of the girder truss span length (measured horizontal displacements I3)

- the upper stripe of the truss girder mountings movable bearings (measured horizontal displacements I4).

In the case of span no. 3, only the measurement of unit deformations on the upper stripe in the half of the longitudinal span (T1) and on the upper stripe of the spar girder (T2) in the middle of its span was made. The location of the measurement sensors is shown schematically in Fig. 3. In the characteristic sections in the bays, No. 2 and 4, PDs-50 inductive sensors and OT-07 inertial sensors are placed side by side. At the same time, a continuous record was recorded from two inductive sensors and two inertia sensors and two strain gauges. Oscillograms of vibration velocity allow estimating the amplitude of dynamic displacements. On the basis of oscillograms of unit deformations, normal stress waveforms were determined at selected points of bearing elements of the bridge spans and extreme stress values. The reference point for the measurements of vertical and horizontal span displacements in the track No. 2 was the adjacent spans in the track No. 1, in the gap between train crossings. The research stand for each of the bays was located on the business pavement on the upper water side, at track No. 1. The load consisted of various combinations of locomotives, locomotives with wagons and draisines. For the purpose of this study, Fig. 4 presents the temporal waveforms of the measured oscillations. The analysis of the results suggests that horizontal (dynamic) vibrations are much greater than vertical vibrations. In tab. 1, dynamic coefficients calculated on the basis of measured extreme stress values, deflections and horizontal displacements in stringers and upper lattice girders were compiled and compared with dynamic coefficients calculated on the basis of the standard [4]. 


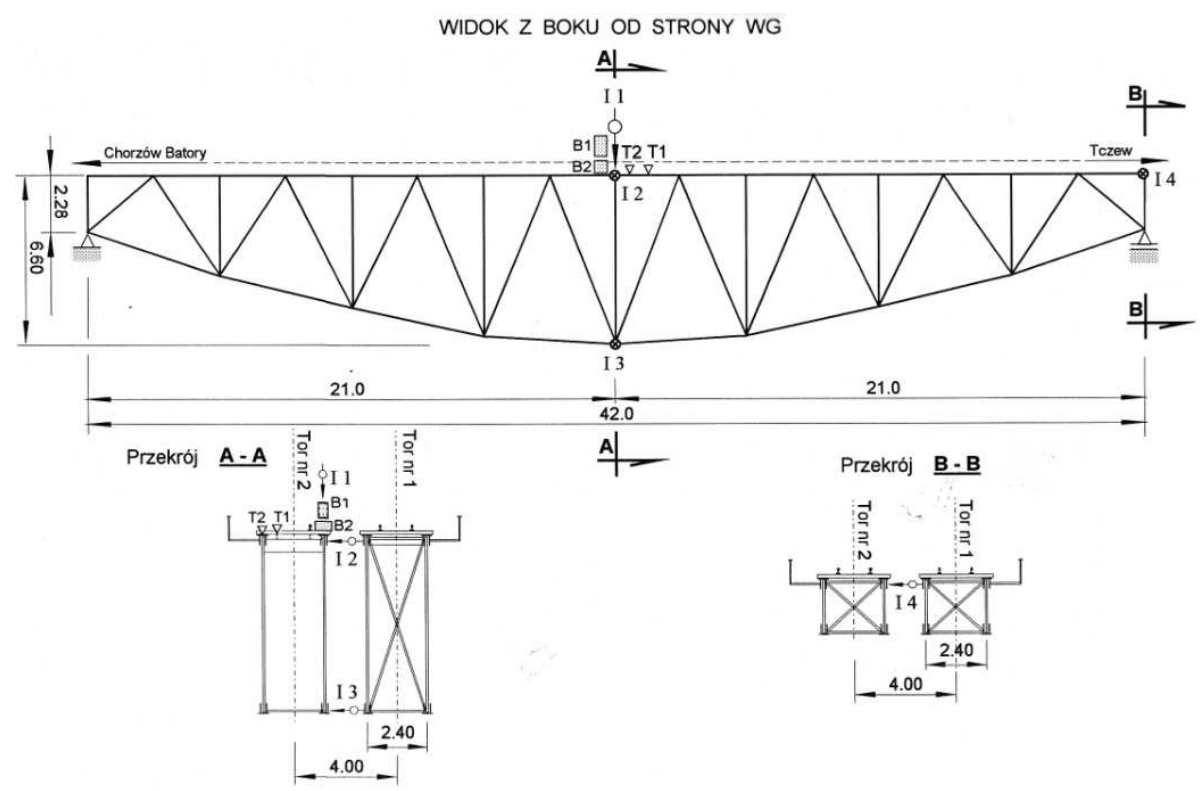

3. Location of measurement sensors on the bridge spans 
a) Przęsło nr 2

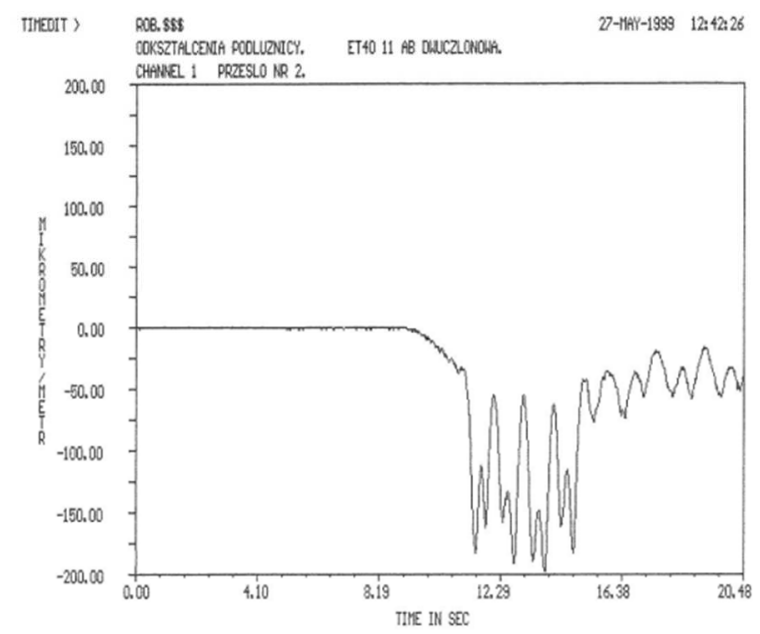

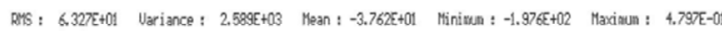

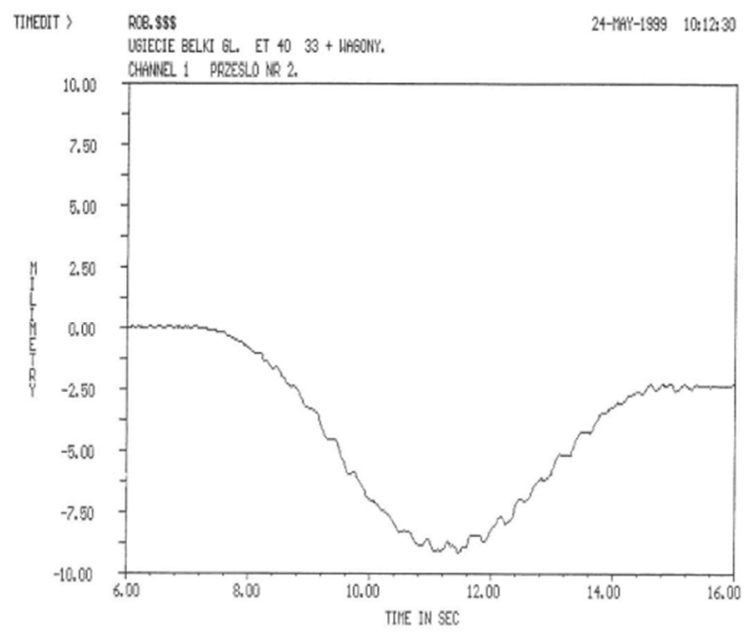

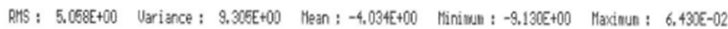

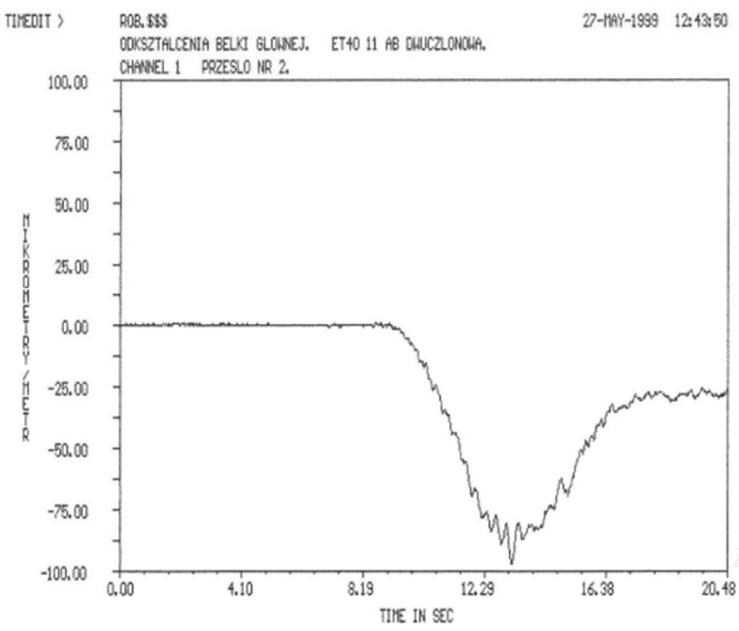

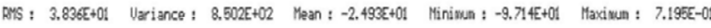

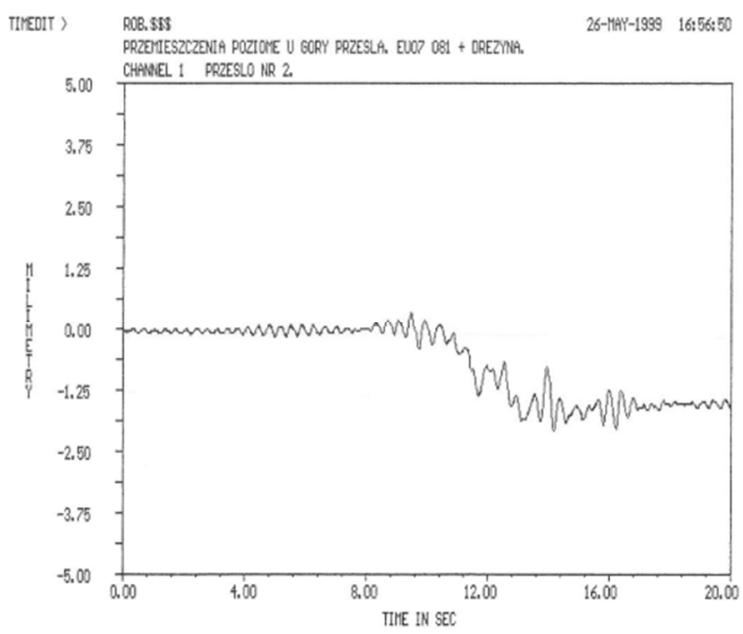

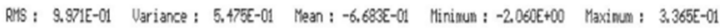

b) Przęsło nr 3

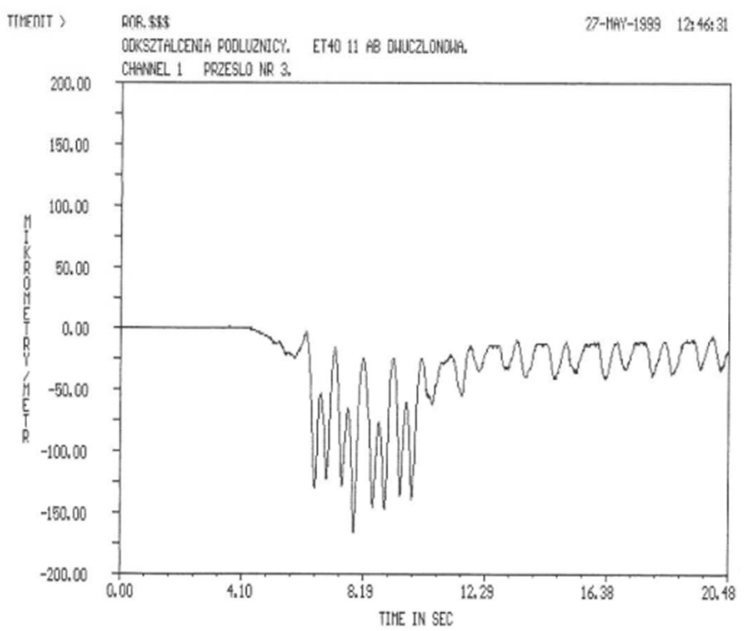

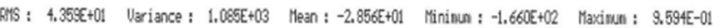

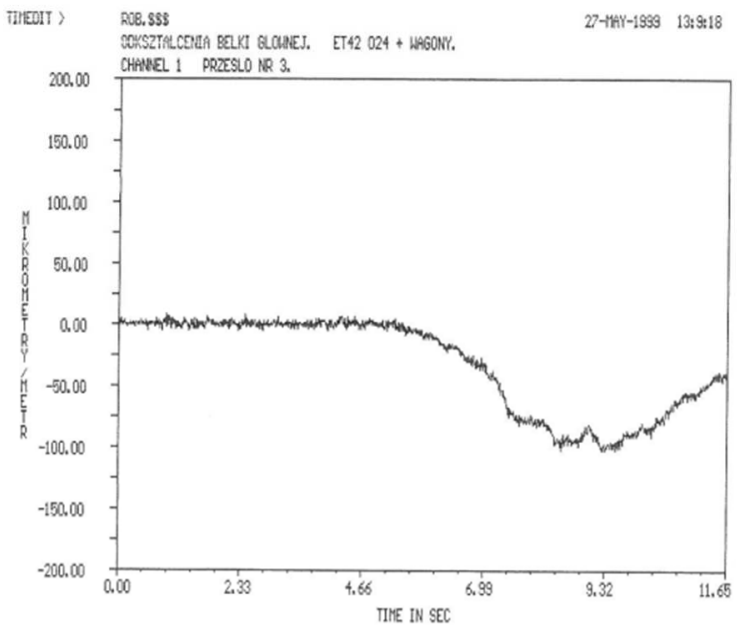

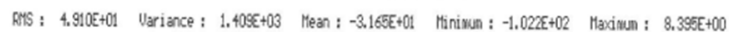



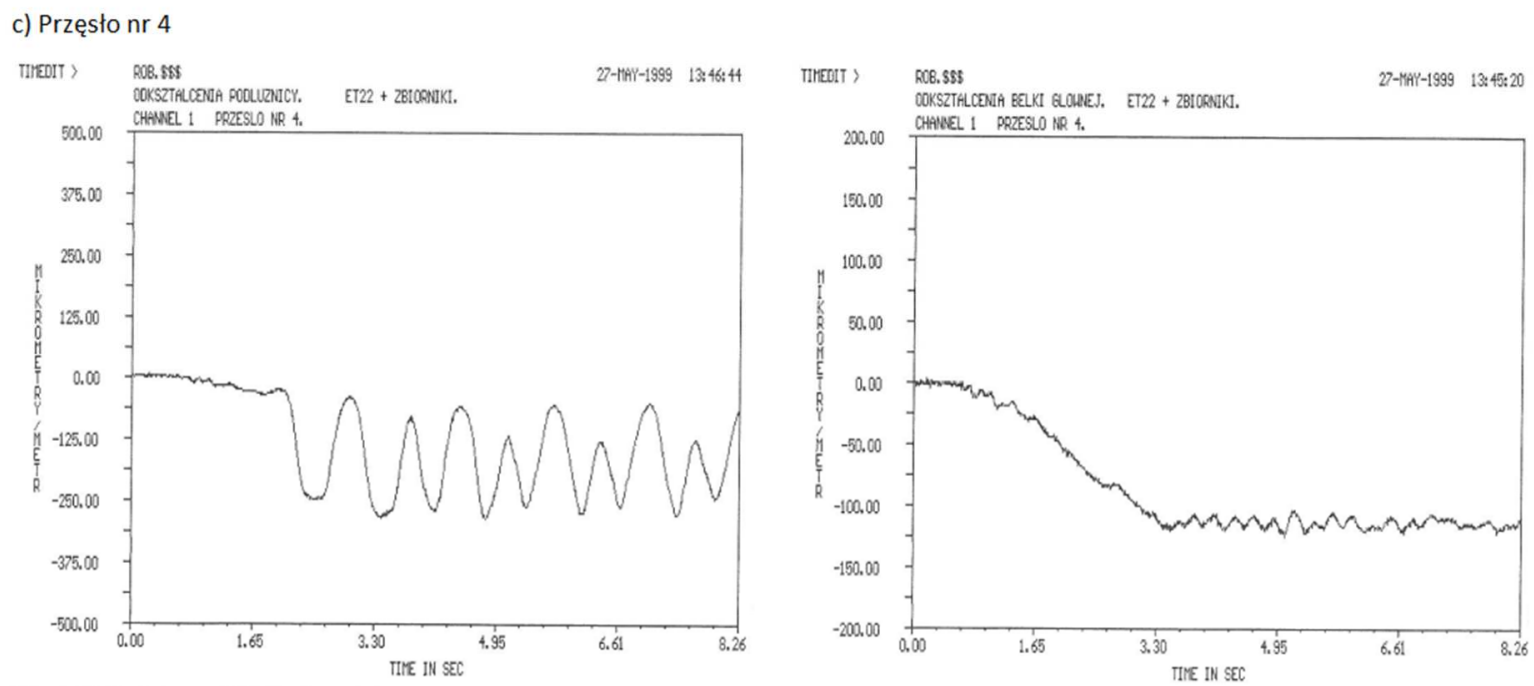

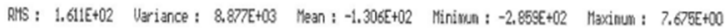

AHS: $9.494 E+01$ Variance : $1.7 m E+03$ Kean : $-8.507 E+01$ Minimum: $-1.242 E+02$ Maximun: $2.878 E+00$
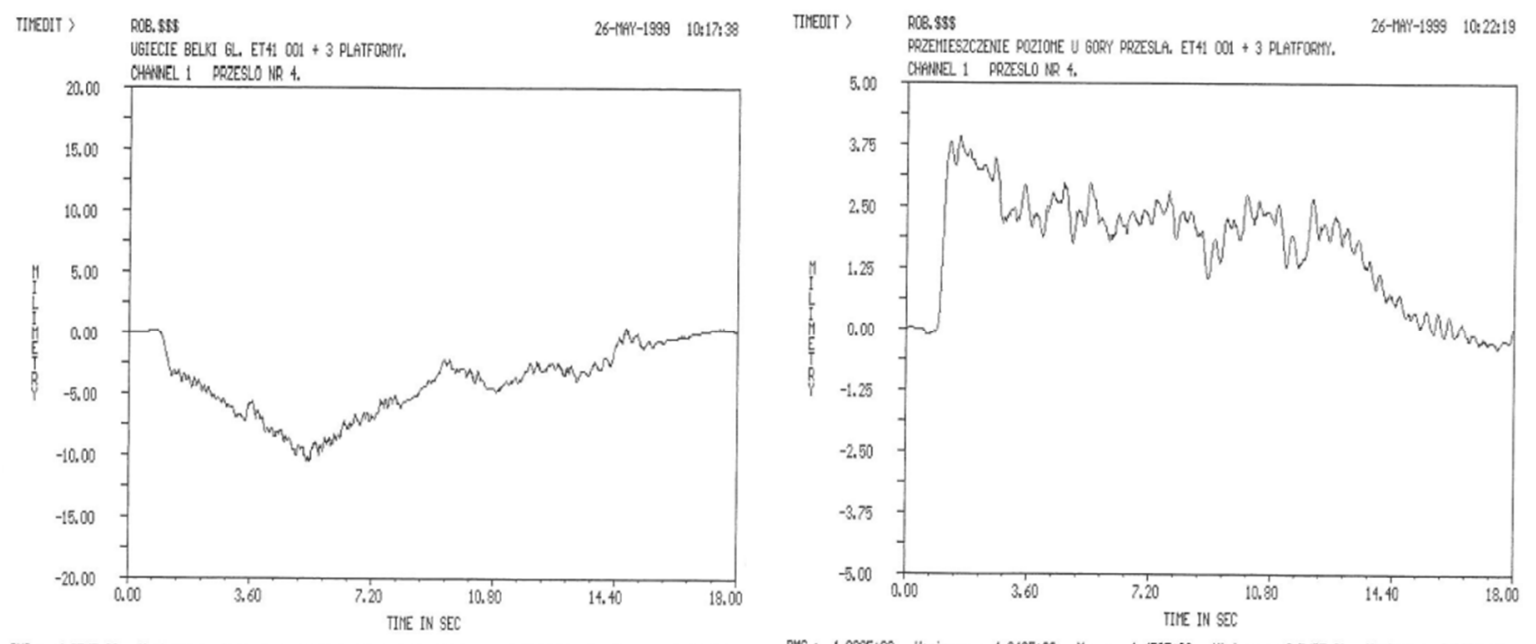

FNS : $4.8765+00$ Uriance : $8.560 E+00$ Maan : $-3.900 \varepsilon+00$ Mininum : $-1.044 E+01$ Maxinun : $5.144 E-01$

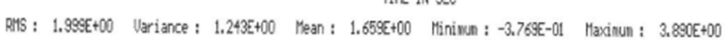

4. Selected results of dynamic tests of truss bridge spans and time course unit deformation (stresses) and displacements

Tab. 1. List of dynamic coefficients calculated on the basis of dynamic tests

\begin{tabular}{|c|c|c|c|c|c|c|c|c|}
\hline \multirow{2}{*}{\multicolumn{2}{|c|}{$\begin{array}{c}\begin{array}{c}\text { Construction } \\
\text { element }\end{array} \\
\text { Stringer } \\
\text { T1 sensor }\end{array}$}} & \multicolumn{2}{|c|}{ Truss span No. 2} & \multicolumn{2}{|c|}{ Truss span No. 3} & \multicolumn{2}{|c|}{ Truss span No. 4} & \multirow{2}{*}{$\begin{array}{c}\begin{array}{c}\text { Normal } \\
\text { dynamic } \\
\text { coefficient }\end{array} \\
1,483\end{array}$} \\
\hline & & 1,534 & $3,4 \%$ & 1,774 & $19,6 \%$ & 1,771 & $19,4 \%$ & \\
\hline \multirow{2}{*}{ 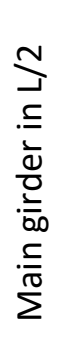 } & 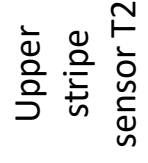 & 1,128 & 7,5 \% & 1,154 & $10,0 \%$ & 1,120 & $6,8 \%$ & 1,049 \\
\hline & 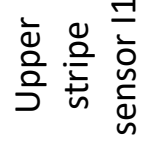 & 1,032 & $1,6 \%$ & - & - & 1,049 & $0,0 \%$ & 1,049 \\
\hline
\end{tabular}


The following conclusions can be drawn from the analysis of the dynamic results of the lattice spans of the bridge under load:

- time courses of unit deformation oscillations in the stringers are very complex, one can notice a significant impact of the dynamic factor; the maximum recorded stress from the operational load occurred in the longitudinal member in span No. 4 and amounted to $\sigma_{d}=$ $60,04 M P a$, the extreme effect of the dynamic factor occurred in the longitudinal member in span no. 3 and amounted $\varphi_{3}=1,774$ with the dynamics share $43,6 \%$,

- oscillations of unit deformations in the upper stripe of the main beam are of quasi-static character with the dominance of statics; maximum stresses occurred in span No. 4 and amounted

$\sigma_{d}=26,06 \mathrm{MPa}$, and the maximum dynamic coefficient is $\varphi_{3}=1,154$ (span No. 3 with dynamics share $13,37 \%$ ),

- vertical displacements (deflections) in the main beam from operational loads have a complex quasi-static nature; the maximum value of the dynamic coefficient is $\varphi_{4}=1,049$ (dynamics share 4,70\%) and the biggest deflections are $q_{d}=10,81 \mathrm{~mm}$ (span No. 4). Purely dynamic frequencies range from $\mathrm{f}=2,046 \mathrm{~Hz}$ ( $\operatorname{span}$ No. 2) to $\mathrm{f}=7,00 \mathrm{~Hz}$ (span No. 4),

- horizontal oscillations are very complex, with a very significant influence of dynamic factor; maximum deflections of the main girder occurred in span No. 4: $\mathrm{q}_{\mathrm{d}}=4011 \mu \mathrm{m}$ (top of span in $1 / 21$ ), $\mathrm{q}_{\mathrm{d}}=4141 \mu \mathrm{m}$ (bottom of span in $1 / 21$ ) where the share of the dynamic factor itself is $749 \mu \mathrm{m}$, which gives as much as $18.1 \%$ and $\mathrm{q}_{\mathrm{d}}=3120 \mu \mathrm{m}$ (top of the span on the support in span No. 4).

The operational deflections are lower than those permitted for lattice girders [5] $\mathrm{f}_{\text {dop }}=1 / 700=60 \mathrm{~mm}$. The structures of the lattice girders in question are characterized by very low damping.

\section{Realized scope of the main repair}

The main repair of bays in the track No. 2 was implemented in 1999 by InterCor company from Zawiercie. Eventually, the scope of repair works included:

- replacement of a riveted span plate with a span of $12.0 \mathrm{~m}$ for a welded span with centering spindles on the upper stripes of the main girders,

- replacement of all stringers with I-beam welded girders, mounting on their upper stripes, on spar girders of spans $2 \div 5$, centering stools and laying of new bridges along with fenders,

- replacement of all gusset plates at the interface between the upper stripes of lattice girders and crossbars and some degraded angle braces, battens, overlay plates, repair of corroded places and replacement of rivets that had corroded heads (mainly in horizontal sheets of upper belts), as well as one overhang (puncture ) from the time of the Second World War,

- execution of a new surface made of UIC 60 rails without the use of rail joints on the bridge, with bumpers on the bridge spans and two-sided flats $\neq 200 \times 20 \mathrm{~mm}$, on both outer sides of the running rails on all bays and installation of the balancing device according to the Id-2 regulations, and external pavement service with a bridge made of galvanized "Mostostal" grates,

- laying of steel bridging plates on bridges between buffer rails,

- elongation of the wings of abutments, superstructure of the front panels along with performing drainage of extreme supports by means of drainage,

- cleaning of dirt and corrosion products and protection of all four lattice spans, span plates and bearings with paint coatings,

- making the embankment stairs on the embankment, on the left bank of the river from the bottom of the water and strengthening with shallow cone-shaped slopes of the embankment of the left-bank bridge abutment. 
There were also no load tests of the spans in track No. 2 after such repairs. As can be seen, the vertical concentrations in intermediate nodes between lattice girders were abandoned. On the object concerned, any attempt to meet the requirements of the Id-2 regulations for laying the surface of UIC 60 ballast type on gravel basement was unrealistic, if only due to the significant increase in the load from the own weight and the enormous scope of works within the bridge reconstruction; thus, an open type railway surface was left in both tracks.

\section{Final conclusions}

The dynamic analysis of the three longest rail bridge spans in track No. 2 in Działoszyn, based on time series of unit deformations (indirectly stresses), vertical displacements (deflections) and horizontal displacements as well as purely dynamic vibrations in operating conditions, indicates a high dynamic sensitivity of the object. This is mainly due to the low transversal stiffness and torsional stiffness of the truss bridge spans so that the passage of rolling stock across the bridge can be perceived as less comfortable and of concern. The results of the research confirmed the necessity of the bridge renewal in 1999, justified the need to stiffen three lattice spans of the object in the previously designed range.

The assessment of the technical condition during the inspection of the facility and the results of measurements carried out under the operational load and their analysis authorize to draw the following conclusions:

1) Until now, immediate repairs of lattice spans have renewed their structure which was previously in poor technical condition (however, no intermediate vertical bracing between lattice girders has been made);

2) The reasons for the damage and improper operation of the span No. $2 \div 4$ were: - the tested structure is characterized by very low transverse or flexural-torsional stiffness, hence such large horizontal displacements (another cause may be unevenness of the track, deviation from longitudinal symmetry, horizontal geometric imperfections of the track, vehicle hooking, side impacts etc.),

- there is no vertical transverse braces between the two lattice girders in the intermediate fields, and thus there is the drawing of gusset plates for forced cooperation at the interface between the upper and transverse beams, which results in cracking of these sheets (several cases have been found),

- the axial spacing of the main truss girders $(2.40 \mathrm{~m})$ is too small in relation to their height $(6.60 \mathrm{~m})$,

- crossbars are too rigid and the longitudinal girders are too small, amounting to only $1.50 \mathrm{~m}$, which means that the rolling stock is "stiffer" with a more dynamic impact on the span structure than if the spacing was $1.70 \mathrm{~m} \div 1.90 \mathrm{~m}$, as in typical solutions, when the ride would be more resilient.

3) The occurrence of significant horizontal oscillations of a complex nature with a significant share of the dynamic coefficient as well as a small vibration damping is particularly dangerous in the support zone, as this may lead to the appearance of damage to the supports.

4) Despite the generally relatively low operating stress, attention is drawn to the fact that the standard dynamic coefficient is exceeded almost every time.

5) All received values of stresses, deflections and horizontal displacements concern limited operating speed up to $30 \mathrm{~km} / \mathrm{h}$; It is estimated that in the case of passing heavier trains and at a higher speed, the dynamic effects obtained would be more significant, which is influenced by the high dynamic sensitivity of the object.

6) Until the stiffening of the truss spans with vertical intermediate concentrations has been achieved, the speed limit for running trains on the bridge up to $15 \mathrm{~km} / \mathrm{h}$ was recommended in the full, designed range. 


\section{Source materials}

[1] Chrobok R., Rabiega J.: „O wynikach dynamicznych badań przęseł mostu kolejowego poddanego renowacji”. I Sympozjum „Diagnostyka i Badanie Mostów”, Opole 46.04.2001, str. 89-96.

[2] Instrukcja Id-2 „Warunki techniczne dla kolejowych obiektów inżynieryjnych”, PKP PLK SA, Warszawa 2005.

[3] Instrukcja Id-16 „Instrukcja utrzymania kolejowych obiektów inżynieryjnych na liniach kolejowych do prędkości 200/250 km/h”, PKP PLK SA, Warszawa 2014.

[4] PN-85/S-10030 „Obiekty mostowe. Obciążenia”.

[5] PN-82/S-10052 „Obiekty mostowe. Konstrukcje stalowe. Projektowanie”.

[6] Rabiega J., Chrobok R.: „Badania pod próbnym obciążeniem dynamicznym mostu kolejowego w km 111,320 w torze nr 1 linii Chorzów Batory - Tczew w Działoszynie". Instytut Inżynierii Lądowej Politechniki Wrocławskiej, Raport serii SPR nr 67/98.

[7] Rabiega J., Chrobok R., Misiński A.: „Badania pod obciążeniem eksploatacyjnym przęseł kratowych w torze nr 2 mostu kolejowego przez Wartę w km 111,320 linii Chorzów Batory- Tczew w Działoszynie". Instytut Inżynierii Lądowej Politechniki Wrocławskiej, Raport serii SPR nr 43/99. 